\title{
Ho Chi Minh thought on solidarity and the social sustainable development in Vietnam
}

\author{
Tuan Phong Tran ${ }^{1, *}$ \\ ${ }^{1}$ Vietnam Academy of Social Sciences, 1 Lieugiai, Badinh, Hanoi, 10000, Vietnam
}

\begin{abstract}
The very humanistic thought is the foundation for Ho Chi Minh develops his thought on great solidarity. Great solidarity is to be built on the humanistic basis is the solidarity oriented to build a social life where the dignity of man is respected, a life without oppression, exploitation and discrimination. Thus, Ho Chi Minh's thought on solidarity serves as the basis to unite all the Vietnamese together in the fight to regain independence for the nation, bring freedom to all Vietnamese and open opportunities for all people to pursuit happy life. Following Ho Chi Minh on solidarity, we would like to argue in this paper that there exists an intimate relation between solidarity and social sustainability or social sustainable development, because the goal of building a Republic mastered by the people is the same as the goal of the cause of construction of a socialist society, which is a socially sustainable society. In other words, the goal of building and developing a socialist republic in Vietnam not only consists in creating a foundation for a wide solidarity of all strata of the people of Vietnam but also serves as a driving force encouraging all the people to participate and contribute to the national cause of development in order to achieve the noble goal of "the rich people, the strong country, the democratic, just, civilized society". In this way, we can see the relation between social solidarity and social sustainable development in Vietnam.
\end{abstract}

\section{Introduction}

Ho Chi Minh thought on solidarity is deeply humanistic. His very thought on solidarity constitutes the foundation and great strength contributing importantly to all successes of the Revolution Cause of Vietnam. The thought on solidarity serves as the basis to connect all the fellow countrymen (compatriots) together in the fight to gain independence for the nation, bring freedom to all Vietnamese and open opportunities for all people to pursuit happy life. Great solidarity always acts as the main driving force in the cause of struggle for national liberation and national unification as well as in the cause of building a Vietnam with "wealthy people, strong country, democratic, just and civilized society".

In Ho Chi Minh thought on solidarity, the core of the great national solidarity is the alliance between workers and peasants, which are the main forces to consolidate and gather all social classes and strata, all ethnic groups, all religions and different political parties for the goal of national liberation from the regime of foreign invaders. This is a wide solidarity

\footnotetext{
${ }^{*}$ Corresponding author: ttuanphong@.gmail.com
} 
beyond all divisions and differences that creates a combined strength to fight together to gain national independence and the right to determine the fate and happiness of every individual as well as entire nation. Here we can see the link between social solidarity and socialism, which is in Ho Chi Minh thought as a society or a republic mastered by the people for the sake of happy development of all people. As the goal of socialism was clearly and intelligibly stated by Ho Chi Minh "Socialism is to make the people be joyful and comfortable"; or "The goal of socialism is to improve constantly people's living standards" or "Briefly and plainly speaking, socialism first of all is to liberate the working people from poverty, bring employment, welfare and happiness to the people". The goal of the republic mastered by the people, the goal of building socialism is the foundation to gather and unite the people. Here we can see the intimate relation between solidarity and socialism and social sustainable development in Ho Chi Minh thought as well as in the practice of building and development of socialist construction in Vietnam nowadays.

\section{Materials and methods}

The author of the paper utilizes the method of analysis methods to analyze and discover the humanistic elements of Ho Chi Minh thought on solidarity. The author also uses the comparison method to find the imtimate relation between Ho Chi Minh thought on solidarity and his concept of building a socialist society.

The materials and methods used in this paper is to demonstrate imtimate relation between solidarity and the building of socialist society as well social sustainability or social sustainable development, because the goal of building a Republic mastered by the people is the same as the goal of the cause of construction of a socialist society, which is a socially sustainable society.

\section{Discussions and Results}

From his arguments the author demonstrates that in Ho Chi Minh humanistic thought, the happiness of man is manifested not only in the development of separate individuals but also in the development of all people. As Ho Chi Minh emphasizes "in a narrow sense, the (term) Man means family, brothers, the relative and friends. In a wider sense it means fellow countrymen (compatriots). In a more wider sense it means the whole humanity". The authentic happiness man is looking for realizes in the complete unfolding of human nature (becoming human). This is the very ideal and ultimate goal of human development. The pursuit of happiness for mankind, for the society and the nation is the main goal of the entire revolutionary life of Ho Chi Minh "my entire life has only one goal: To strive for the interest of the Nation and happiness of the people... Any where, any time, I only pursuit only one goal: To do for the sake of national interests and people's benefits" or "I have only one desire, the most earnest desire, that our country be completely independent, our people be completely free, all our compatriots have enough food, clothing and housing, are able to learn and make progress and enjoy a fruitful, free and happy life".

The very humanistic thought is the foundation for Ho Chi Minh develops his thought on great solidarity. Great solidarity, which is to be built on the humanistic basis, is the solidarity oriented to build a social life where the dignity of man is respected, a life without oppression, exploitation and discrimination. In the context when the country was under the rule of foreign invaders, the most important task is to unite all the people living under the colonial oppression and exploitation for the cause of revolution. Revolution is the common cause of the entire nation, all the Vietnamese people regardless of race, religion and beliefs. The humanistic goal of the Revolution is, therefore, able to unite widely the people. More 
than anyone, Ho Chi Minh understands the value of national solidarity: "Thanks to solidarity that the people of Vietnam have won over colonialism, carried out successfully the August Revolution and brought the Resistance War to victory. It is thanks to the great entire people solidarity that our Vietnam will definitely be united".

While addressing the content of solidarity, Ho Chi Minh states clearly "the great solidarity means first of all the solidarity of the majority of the people, the majority of the people are the workers, peasants and other laboring classes. That is the root of the great solidarity. It is similar to the foundation of a house, the root of a tree. However, even when there is a firm foundation and good root the solidarity, it is necessary to unite other classes and strata of the people". The core of the great national solidarity is the alliance between workers and peasants, which are the main forces to consolidate and gather all social classes and strata, all ethnic groups, all religions and different political parties for the goal of national liberation from the regime of foreign invaders. This is a wide solidarity beyond all divisions and differences that creates a combined strength to fight together to gain national independence and the right to determine the fate and happiness of every individual as well as entire nation "the Government and the entire people of Vietnam are determined to fight for the right of unity and independence for the country in order for the culture as well as politics, economy, beliefs and morality to be developed freely".

Obviously that the people had no freedom to develop when the country lost its sovereignty, the whole nation lived in slavery. The very humanistic thought led Ho Chi Minh to communism. Starting from his patriotism, the love for the compatriots, in his journey for the way to salvage the country, gain national independence and liberate the people for slavery, Ho Chi Minh found that communism is the appropriate way to achieve his noble goal "In the beginning, it was patriotism and not communism which impelled me to believe in Lenin and the Third International. Gradually, proceeding step by step in the course of the actual struggle, and combining the theoretical study of Marxism-Leninism with practical work, I reached the point where I understood that only socialism and communism can liberate the oppressed peoples and the workers of the whole world from slavery".

When the national independence has been gained, Ho Chi Minh realized that the tasks of the Government are to aim at the sole goal of pursuing freedom and happiness of the people". Therefore, right after the success of the August Revolution, Ho Chi Minh proposed immediate works to be done in order to create opportunities for all people do develop fully their potentials. Concretely, Ho Chi Minh listed the immediate works and tasks as follows:

"1. To make the people have food

2. To make the people have clothing

3. To make the people have shelter

4. To make the people have education".

If the tasks of making the people have food, clothing and shelter are to meet basic needs for man to exist, the task of making the people have education means to create opportunities for the people to develop freely. In his letter to students, Ho Chi Minh says that "we have to rebuild the country inherited from our ancestors and catch up with other countries in the globe", this task can be done because the students of a new generation "are able to acquire the education of a independent country, the education that transform you into the citizens useful for the nation of Vietnam, the education that can develop comprehensively your given potentials". The goal to "develop comprehensively your given potentials" not only brings about happiness for every man but also helps rebuilt the country left to us by the ancestors in order to catch up with other countries in the world. This is the task of the country "the common work that every descendant of the Dragon and the Fairy, regardless of being young or old, male or female, rich or poor, must take part in and strive 
for". So we can see that the goal of building and developing a socialist republic in Vietnam not only consists in creating a foundation for a wide solidarity of all strata of the people, all ethnic groups living in the territory of Vietnam but also serves as a driving force encouraging all the people to participate in the national cause of development. Such a republic polity is the achievement and common property of the people and must be mastered (and managed) by the people.

Seeing from the prespective of social sustainable develpment we can see the link between solidarity and human development in Ho Chi Minh understanding. He realized clearly that only after the nation regained independence and the people are free, every citizen of Vietnam is desired to be recognized as a master and expected to be provided the necessary conditions to exercise the right of mastership. However, it is important to realize that the capacity to be master is not naturally given but it is closely related to education and the process of human development. This capacity expresses the level of human development, the level in which man realizes his potentiality, his or her "essential powers". Moreover, human development or the development of mastership capacity always takes place at a concrete socio-historical context, in a specific cultural tradition. Here we can see the dialectical relationship between individual human development and the cultural tradition of human communities. A cultural tradition exists as the result of the development of human nature, the fruit of the confirmation of the subjectivity of free development of man and human generation, but on the other hand, a cultural tradition also serves as the condition necessary for human development, as a socio-historical environment for the formation of social subjects of future human generation. In this context, democracy can be seen under the aspect of formation and development of a human community as the subject of development.

Following the materialist understanding of Marxism we can see that the superiority of the socialist regime as a more perfect social system, a higher level of development than that of capitalism, must be expressed in that it overcomes the disadvantages of capitalism to ensure that all people have the opportunity to develop, and be equal in their participation and contributing to the development of the society. The sustainability of such social development must be reflected in social development policies with a wide consensus and support from the people, and which maximize the active participation of the people. Socialist socialism must be a system that is organized and administered in a truly democratic manner to ensure the mastery of all citizens, and it must be a regime that takes the basic rights of the people as the goal and starting point of development policies. The regime in which the people must be true owners and social justice is guaranteed. Transparent legal systems are essential conditions to ensure fairness of rights, fairness of development opportunities, justice in the distribution and utility of common goods for all people to truly have chances to participate in and benefit from the fruits of development, as well have opportunities to bring into full play their creative potentials.

In the present development period of the Vietnamese revolution, together with Marxism-Leninism, Ho Chi Minh's thought is the foundation of the thought, the guideline for the actions of the Communist Party of Vietnam and the people. The Communist Party of Vietnam has inherited and developed creatively the views of Ho Chi Minh on solidarity and socialism. The overarching goal of the cause of socialist construction in our country is "rich people, strong country, democratic, just and civilized society." People are not only the direct masters who express the creativity and autonomy in the implementation of this goal, but also the masters of the power. They are also the beneficiaries of the achievements of the development. Solidarity, creativity and proactiveness of the people will create synergy to achieve the country's development goals. Our Party also affirmes that, for the Vietnamese revolution, the red thread throughout the path is the national independence associated with socialism. "The superiority of socialism that our people are building must be directed 
towards the full and synchronized realization of the system of the goals of: rich people, strong country, democratic, just and civilized society. The thorough thought of the Vietnamese revolution is that national independence associated with socialism. For the Vietnamese, only socialism guarantees (the goal of) the rich people, the strong country, the democratic, the just, the truly civilized society. This is the earnest aspiration of all Vietnamese people after the country gained independence and national reunification. "

\section{Conclusion}

In conclusion we would like to say that Ho Chi Minh's thought on solidarity serves as the basis to unite all the Vietnamese together in the fight to regain independence for the nation, bring freedom to all Vietnamese and open opportunities for all people to pursuit happy life. According to Ho Chi Minh thought, the goal of building and developing a socialist republic in Vietnam not only consists in creating a foundation for a wide solidarity of all strata of the people of Vietnam but also serves as a driving force encouraging all the people to participate and contribute to the national cause of development in order to achieve the noble goal of "the rich people, the strong country, the democratic, just, civilized society". In this way, we can see the relation between social solidarity and social sustainable development in Vietnam.

Thus, we can see that the goal of building a republic mastered by the people is the same as the goal of the cause of construction of a socialist society, because the goal of socialism was clearly and intelligibly stated by Ho Chi Minh: "Socialism is to make the people be joyful and comfortable" or "Briefly and plainly speaking, socialism first of all is to liberate the working people from poverty, bring employment, welfare and happiness to the people". The goal of the republic mastered by the people, the goal of building socialism is the foundation to gather and unite the people. Here we can see the intimate relation between solidarity and socialism in Ho Chi Minh thought as well as social solidarity and social sustainable development in Vietnam

\section{References}

1. C. M. Ho, Complete Work (National Publishing House, Hanoi, 1995)

2. Communist Party of Vietnam, The Documents of the 12th Party's Congress (National Political Publishing House, Hanoi, 2016)

3. N. Anh, Asian Smallholders in Comparative Perspective, 307-344 (2019), DOI:10.2307/j.ctvrxk2k6.14

4. V. Nguyen Marxism After Ho Chi Minh. In Prelinger M. \& Schalit J. (Eds.), Collective Action: A Bad Subjects Anthology, 167-170, (Pluto Press, London 2004), DOI:10.2307/j.ctt18fsd0s.38

5. R. Fichtenbaum, G. Welty, Forum Soc. Econ., 151-170 (1985) DOI: doi.org/10.1007/BF02751474

6. A. Mason, Solidarity. Retrieved May 14, 2019, from The Routledge Encyclopedia of Philosophy: https://www.rep.routledge.com/articles/thematic/solidarity/v-1(1998).

7. A. Prainsack, A. Buyx, Solidarity: Reflections on an Emerging Concept (London, NcoB, 2011).

8. H. Brunkhorst, Solidarity: From Civic Friendship to a Global Legal Community. (Cambridge, MA: MIT Press, 2005)

9. C. Calhoun, Public Culture 14(1), 147-171. (2002). 
10. J. S. Coleman, Foundations of Social Theory (Cambridge, MA, Harvard University Press, 1990).

11. E. Durkheim, The Division of Labor in Society ( New York, Free Press. 1964).

12. E. Durkheim, On Morality and Society (Chicago, University of Chicago Press, 1973).

13. T. Fararo, D. Patrick (eds.) The Problem of Solidarity: Theories and Models (New York, Routledge, 1998).

14. Komter, Social Solidarity and the Gift (Cambridge University Press, 2005).

15. R. Rorty, Contingency, Irony, and Solidarity (Cambridge University Press, 1989).

16. S. Scholz, Political Solidarity (The Pennsylvania State University Press, 2008).

17. C. Taylor, Charles. Sources of the Self: The Making of the Modern Identity (Cambridge, MA: Harvard University Press, 1989).

18. E. Voland, Solidarity, 157-172 (Dordrecht, Kluwer, 1999).

19. L. Wilde, Global Solidarity (Edinburgh, Edinburgh University Press, 2013) 